\title{
Use of a Combination of MRSS-ANP for Making an Innovative Landfill Siting Decision Model
}

\author{
Mohammad K. Younes, ${ }^{1}$ N. E. Ahmad Basri, ${ }^{1}$ Z. M. Nopiah, ${ }^{1}$ \\ H. Basri, ${ }^{1}$ and Mohammed F. M. Abushammala ${ }^{2}$ \\ ${ }^{1}$ Department of Civil and Structural Engineering, Universiti Kebangsaan Malaysia, 43600 Bangi, Selangor, Malaysia \\ ${ }^{2}$ Department of Civil Engineering, Middle East College, Knowledge Oasis Muscat, P.B. No. 79, 124 Al Rusayl, Oman \\ Correspondence should be addressed to Mohammad K. Younes; mohyoumoh@hotmail.com
}

Received 4 April 2015; Revised 7 June 2015; Accepted 8 June 2015

Academic Editor: Jurgita Antucheviciene

Copyright (C) 2015 Mohammad K. Younes et al. This is an open access article distributed under the Creative Commons Attribution License, which permits unrestricted use, distribution, and reproduction in any medium, provided the original work is properly cited.

Landfill siting is a complex, multicriteria decision-making problem that needs an extensive evaluation of environmental, social, land use, and operational criteria. Integration of a median ranked sample set (MRSS) and an analytic network process (ANP) has been implemented to rank the associated criteria and select a suitable landfill site. It minimizes the uncertainty and the subjectivity of human judgments. Four groups of experts with different backgrounds participated in this study, and each group contained four experts. The respondent preferences were ranked in a 4-by-4 matrix to obtain the judgment sets for the MRSS. These sets were subsequently analyzed using ANP to obtain the priorities in the landfill siting criteria. The results show that land topology and distance from surface water are the most influential factors, with priorities of 0.18 and 0.17 , respectively. The proposed integrated model may become a promising tool for the environmental planners and decision makers.

\section{Introduction}

Facility site selection model is complex and needs extensive assessment and comparison efforts [1]. Proper landfill siting is essential to reduce the environmental and health impacts associated with its construction and operation [2]. In general, solid waste treatment and disposal facilities belong to a group of obnoxious or undesirable facilities, and, therefore, landfill siting faces two major challenges: (i) social objection represented by a phenomenon known as BANANA (build absolutely nothing anywhere near anyone) or NIMBY (not in my back yard) and (ii) the large number of technical, social, and environmental factors that must be considered in selecting the best location to minimize nuisances and maximize efficiency and social acceptance [3]. Solid waste landfill remains a convenient method for the disposal of an increasing amount of municipal solid waste, notably in developing countries [4]. Landfill site selection requires a different type of criteria processing to account for the unequal criteria importance [5-9]. Moreover, increasing the number of participating parties in the decision-making process widens its popularity and strengthens it [10], but analyzing and homogenizing the preferences of these stakeholders are complex issue, especially with conflict of interests among the participated interest groups.

Decision support systems like the analytic hierarchy process (AHP) and its generalization (ANP) have been widely implemented to handle the complex problems. Multicriteria decision-making (MCDM) using ANP is composed of the following steps: (i) identifying the factors and the components within the network together with their interactions and relations; (ii) conducting pairwise comparisons among the network elements and the main/subcriteria to build the unweighted supermatrix; (iii) obtaining the weighted supermatrix via weighting the blocks of the unweighted supermatrix by the corresponding priorities of the clusters (from which the resulting matrix is column stochastic); and (iv) developing the limit matrix by increasing the power of the weighted supermatrix until the weights converge [11].

The ANP is implemented to drive the relative priorities of the criteria using the judgment of individuals [12]. However, ANP implementation requires higher number of judgments 
TABle 1: Definition of the scale of importance [58].

\begin{tabular}{lcl}
\hline Intensity of importance & Definition & Explanation \\
\hline 9 & Extremely important & This activity is of the highest possible order of affirmation \\
7 & Strongly important & This activity is strongly favored (dominant) over other activities \\
5 & Moderately important & This activity is moderately favored over other activities \\
3 & Slightly important & This activity is slightly favored over other activities \\
1 & Equally important & This activity equally contributes to the objective \\
$2,4,6$, and 8 & & Intermediate importance between two adjacent responses \\
\hline
\end{tabular}

than AHP. Because of the ability of ANP to treat the interactions and feedback and thus justify the decision [13], ANP is widely used in many decision-making applications. However, ANP-based decisions are limited by the uncertainty in judgment during the pairwise comparison [14]. A previous study [1] combined ANP and data envelopment analysis to leverage both the available qualitative and quantitative data for the location of a landfill site. Additional studies $[15,16]$ implemented ANP to suggest the best location of a landfill site. Several researchers $[17,18]$ integrated a fuzzy set, AHP, and a weighted linear method to prioritize the site evaluation criteria and applied this process using Geographic Information System (GIS) software. Moreover, hybrid model of an ANP and a triangular fuzzy function were used by [14] to measure remedial countermeasures. A landfill site suitability analysis using an AHP and a compromised programming method was also reported [19]. An AHP was applied to find the weighted site evaluation criteria and was used in GIS to suggest the best landfill location [20].

The ranked sample set (RSS) was first proposed by Mc Intyre in 1952 to estimate the population mean, and since that time it was modified and developed many times [21, 22]. Applying of the RSS to estimate the population mean and median leads to notable gains in precision [23]. The MRSS is an adaptation of RSS, and, in this method, only the median observation is considered from each of randomly selected sets. The MRSS is advantageous (relative to RSS) because it minimizes the ranking errors and enhances the estimation efficiency [24]. The MRSS proposes promising applications in environmental researches because of its capability to represent a population without extensive observations [25]. For instance, the spray deposits on the leaves of apple trees were assessed using RSS [26]. An RSS method was also applied to collect samples from gasoline stations for analysis intended to verify the conformity of these stations with clean air regulations [27]. Prior sample knowledge was also integrated with RSS to minimize the cost of evaluating a stream habitat region for salmon [28].

This study presents a model to reduce the imprecision and vagueness of the human decision-making. It identifies the relative importance of landfill siting criteria as a case study. The presented model leverages the power of an expert system to extract knowledge that is subsequently applied to a hybrid MRSS-ANP system to obtain the criteria weights.

\section{Methodology}

Landfill siting is a multicriteria decision-making process. The proposed model decomposes this process into three levels: problem construction, criteria analysis, and selection [7]. Problem (case) construction determines the problem, aims, assessment criteria, the experts, and their groups. Criteria analysis extracts the expert knowledge and performs data analysis using MRSS. The selection step determines the importance of the landfill siting criteria using ANP and the rank of the final priorities.

2.1. Case Construction. The problem construction starts with a literature review used to determine the main and subcriteria of the landfill site selection. There are no general approaches to select a set of evaluation criteria but it can be selected through an examination of the relevant literature, analysis study, and expert opinions [29]. However, the criteria selection was based on the usage (the most commonly found in literature), expert opinions, and data availability. These criteria were subsequently arranged in a hierarchical structure, and the hierarchical tree defines the most general network. The landfill siting criteria were classified into four main groups: social $[30,31]$, operational $[16,18]$, environmental $[32,33]$, and land use [34-36]. Moreover, the subcriteria fall under each main group, as shown in Figure 1. After the initial classifying, the experts were determined and divided into four clusters (groups). A cluster analysis splits the data into meaningful groups that are usually associated or share characteristics [37]. The resulting groups involved the governmental sector, private sector, academia, and nongovernment organizations interested in solid waste and environmental issues.

A developed questionnaire asked the stakeholders to draw pairwise comparisons among the criteria and the subcriteria with respect to landfill site selection. The used questionnaire takes into account the interactions and feedbacks between the criteria. Table 1 shows the intensity of the importance of the criteria. The odd-numbered rankings were used to determine the criteria importance, whereas the entire range from 1 to 9 was used to develop the ANP multicriteria decision analysis.

2.2. Criteria Analysis. The stakeholders preferences were grouped into four random sets. Each set consists of the 


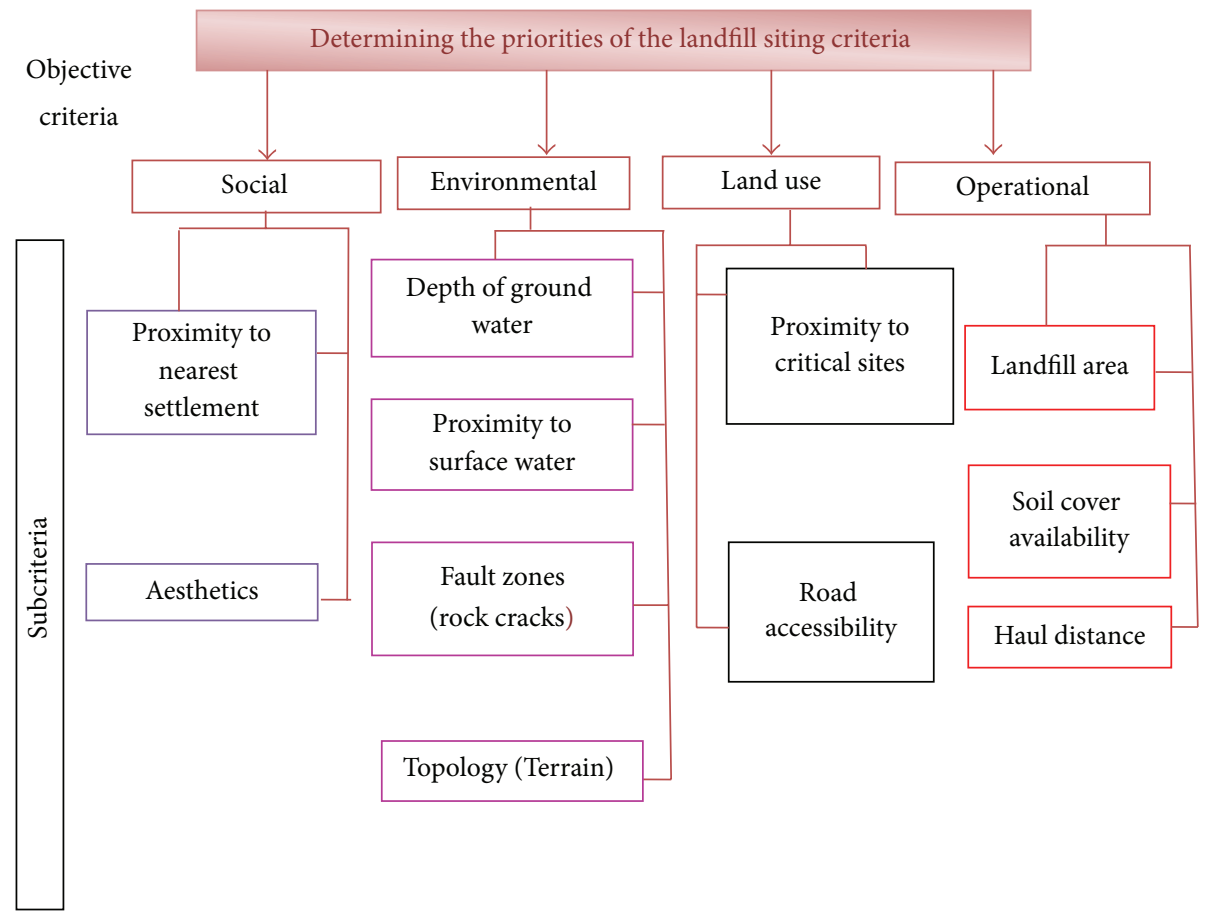

FIGURE 1: Hierarchical structure of the landfill siting criteria.

TABLE 2: Comparison of the importance of land use with the importance of operation methods.

\begin{tabular}{lcccc}
\hline Sector & Government & $\begin{array}{c}\text { Private } \\
\text { sector }\end{array}$ & NGO & Academia \\
\hline Expert group number 1 & 7 & 0.33 & 0.20 & 1 \\
Expert group number 2 & 1 & 3 & 1 & 0.14 \\
Expert group number 3 & 7 & 5 & 3 & 7 \\
Expert group number 4 & 3 & 3 & 3 & 0.20 \\
\hline
\end{tabular}

responses of one government, private, academia, and NGO respondent. The respondents are experts in the field of solid waste management and landfill siting issues through their work experience. Table 2 shows an example of one of the comparisons by displaying the obtained preferences of the respondents and their sets. Next, these responses were ranked in increasing order for each individual set, as shown in Table 3. After that, the importance of the landfill siting criteria was obtained using the second scenario [21]:

(i) If the sample size, $n$, is odd, then the median is selected by $((n+1) / 2)$ th. This observation can be denoted as $X_{(((n+1) / 2): n)}$, and the general formula is

$$
\left\{X_{(((n+1) / 2): n) 1}, X_{(((n+1) / 2): n) 2}, \ldots, X_{(((n+1) / 2): n) n}\right\} \text {. }
$$

(ii) If the sample size $n$ is even,

then the median is selected by $(n / 2)$ th. This observation can be denoted as $X_{((n / 2): n)}$, and the general formula is

$$
\left\{X_{((n / 2): n) 1}, X_{((n / 2): n) 2}, \ldots, X_{((n / 2): n) n}\right\} \text {. }
$$

2.3. Final Priority Selection. The study aim is to determine the overall priority of each criterion and apply it in the case study considering the interactions and the feedbacks among the main and subcriteria. ANP systematically breaks down the problem to justify the decision $[38,39]$. To capture the interactions and feedback, a hierarchical framework that contains all main and subcriteria must be constructed. Thus the comparisons can be performed and synthesized to determine the unweighted, weighted, and limit matrices that determine the priorities of importance of the landfill siting criteria. Figure 2 shows the interactions and feedback between the landfill siting components. An arrow and/or loop arrow specify the dependence and feedback for which the two-side (double) arrows indicate the influences between the elements on both groups. The inner-dependence or selffeedback is indicated by a loop arrow at the top of each group.

The resulting relative importance sets from the previous step contain the preferences of government, private, NGO, and academic stakeholders and are used in the ANP. This step is repeated for the sixty-three pairwise comparisons to build the comparison matrix (unweighted supermatrix). The inputs of the supermatrix depend on the presence and the type of dependence among the group elements that are shown in Figure 2. The matrix is subsequently input into the Super Decisions (version 2.2) software to develop the weighted and limit matrices [40]. The weights obtained in the limit matrix represent the final importance priorities. Finally, the integrated landfill siting procedures are summarized in Figure 3. This figure illustrates the guidelines for such decision-making problem.

2.4. Case Study. Selangor is the most populated and highly developed state in Malaysia; it has a diversified economy 


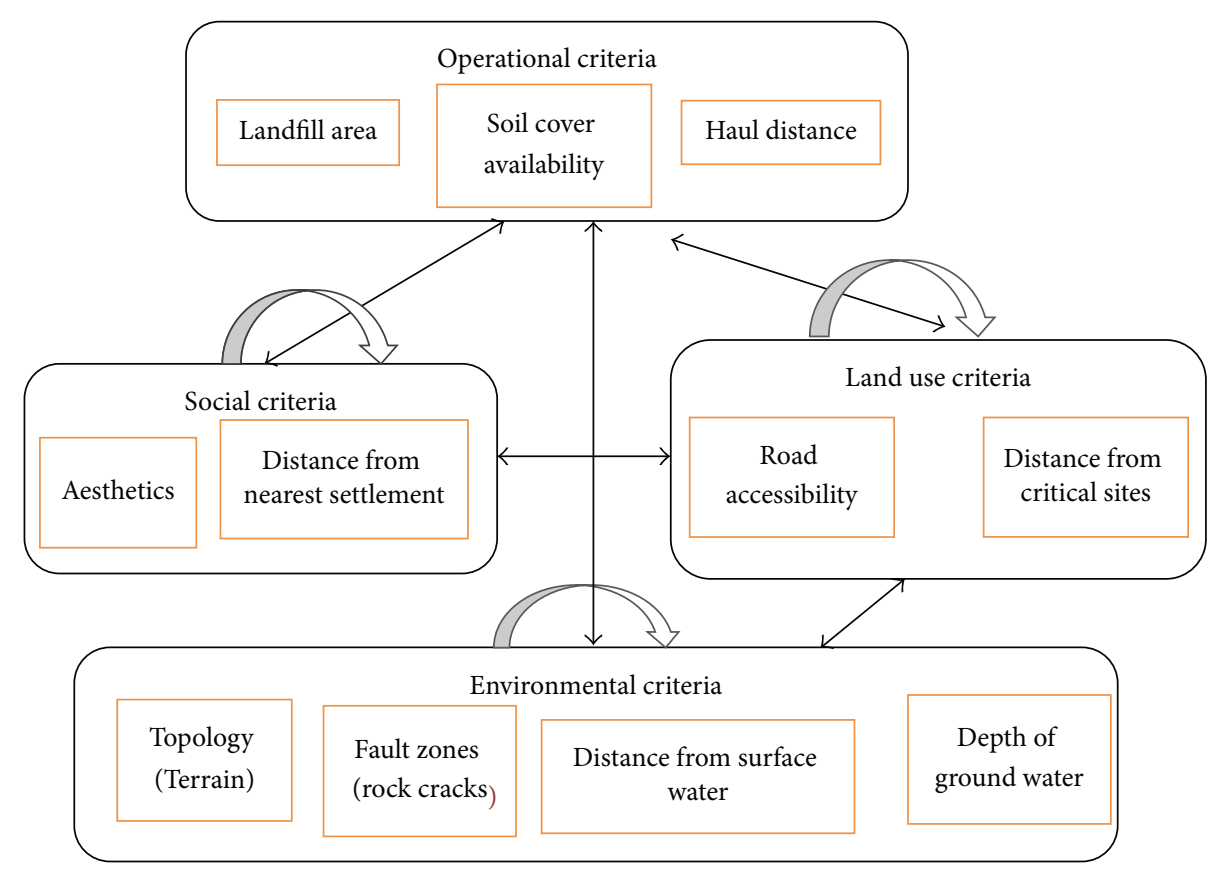

Figure 2: Interactions and feedback between criteria.

including industry, commerce, agriculture, and tourism. Moreover, Selangor completely surrounds two federal territories, which are Kuala Lumpur (KL), the national capital of Malaysia, and Putrajaya the federal capital. The areas of Selangor, Kuala Lumpur, and Putrajaya are 7,930, 243, and $92 \mathrm{~km}^{2}$, respectively. There is a great demand to depend on scientific approach for determining a landfill site in Selangor due to increasing amounts of solid waste and land scarcity. Thus Boolean logic was implemented to exclude unsuitable areas that cannot be used as a disposal site [19]. The exclusion is done by overlaying technique and in dependence on constraint factors [6, 41]; these factors are based on Malaysian guidelines for development of solid waste sanitary landfill [42]. However, the Boolean logic is restrictive in nature [43]; thus, by its implementation, the study area is classified into two classes suitable area with value (1) and unsuitable area with value (0) as shown in Figure 4 and described in (3):

$$
\text { Boolean Suitablity Index }=\prod_{j=1}^{n} b_{j},
$$

where Boolean Suitability Index has a value (0 or 1$), b_{j}$ is the Suitability Index for each constraint criterion and has a value ( 0 or 1$)$, and $n$ the total number of constraint criteria [2]. Finally, the potential landfill sites were suggested based on assumed landfill area and ranked using the obtained MRSS-ANP weights and Suitability Index (SI), which is the sum of products of the standardized score of each criterion multiplied by the weight of each criterion:

$$
\mathrm{SI}=\sum W_{i} * C_{i},
$$

where $W_{i}$ is weight of factor $I$ and $C_{i}$ is criteria grading of factor map $i[34]$.

\section{Results and Discussion}

3.1. Case Construction. Figure 1 shows the developed hierarchical structure of the landfill site evaluation criteria. Each main criterion has an ultimate goal, that is, to maximize the preservation of nature (environmental), acceptance by the public (social), or appropriateness of the site (land use). Additionally, the target of operational criteria is minimizing the costs. The eleven subcriteria that share common characteristics were grouped together under the main criteria. Since the solid waste hauling distance, availability of soil cover for daily landfill operations, and landfill area are controlled during landfill construction or operation, they were classified under one group (operational) [43].

Moreover, land use involves the locations of critical sites highways and roads that are identified by the town planning department and these locations are highlighted for specific consideration in future plans. Examples of critical sites include airports, hospitals, railway, and other institutes [18]. Landfills serve large communities, but only subset of those communities commonly experiences the impacts of the landfill (typically the ones that are located near it) [44]. However, these effects can be minimized using special arrangements designed to reduce the nuisances caused during waste transportation and enhance the landscaping around the landfill to create a green buffer. The environmental criteria aim to conserve air, water, and soil and to minimize land altering activities [32] by applying the best available techniques and environmental practices to achieve these goals.

Figure 2 displays the dependence and feedback among the criteria. The environmental criteria do not relate to the aesthetics or distance from the nearest settlement; therefore, an interconnection or feedback between the environmental 


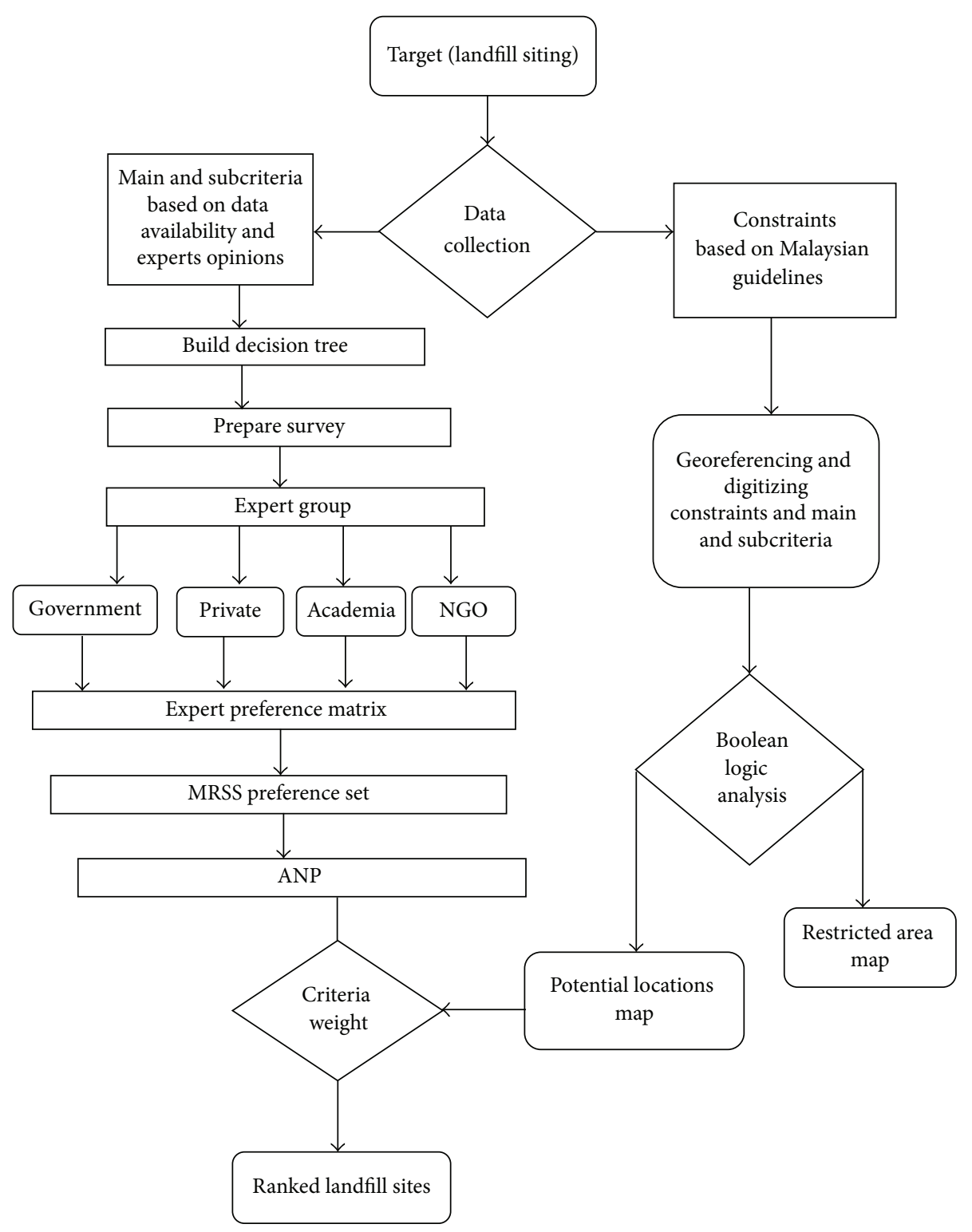

FIGURE 3: The landfill site selection algorithm.

and social main group is not shown. One or more of the remaining subcriteria relate to an additional criterion from outside of the group. For example, reciprocal effects were noted between the land topology and surface water. Surface water alters the land topology, whereas the topology affects the water runoff and maximizes or minimizes the movement of pollutants. Pairwise comparisons were used to compare the criteria and to allocate the criteria priorities using the Saaty method [39, 45]. The respondents were divided into four stakeholder sets to reduce vagueness and enhance quality.

3.2. Criteria Analysis. Based on the interactions and feedback among the criteria, sixty-three pairwise comparisons were required. The preferences of each respondent were recorded for each comparison. Every set of responses contained the opinion of one expert from each group, that is, government, private, academia, and NGO. Therefore, the response range within the same set is relatively large because of the conflicts of interest of the stakeholders. The expert responses within the same group were observed to converge, but outlier responses were noted due to human nature and the various backgrounds of the experts. For instance, one governmental expert might emphasize environmental concerns because of personal involvement in environmental regulations, whereas another governmental expert may emphasize planning and land development because of personal involvement in a planning department. Similarly, one NGO representative could emphasize conservation, whereas another NGO representative might emphasize service to society. Therefore, points of view can diverge within an identical group.

Sixty-three pairwise comparisons were performed to identify the relative importance of the landfill siting criteria. An example of one of these comparisons is shown in Table 2. 


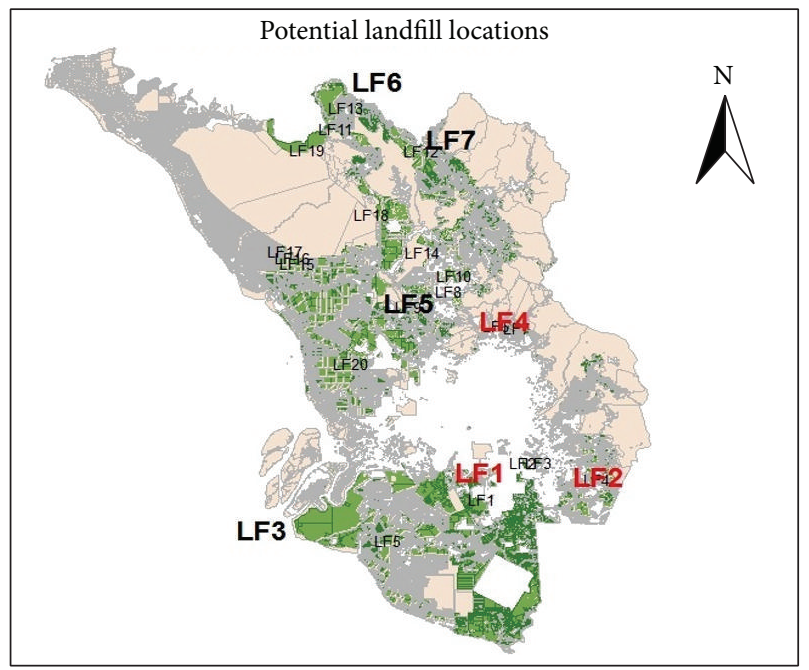

Selangor state

Landfill potential area

(a)
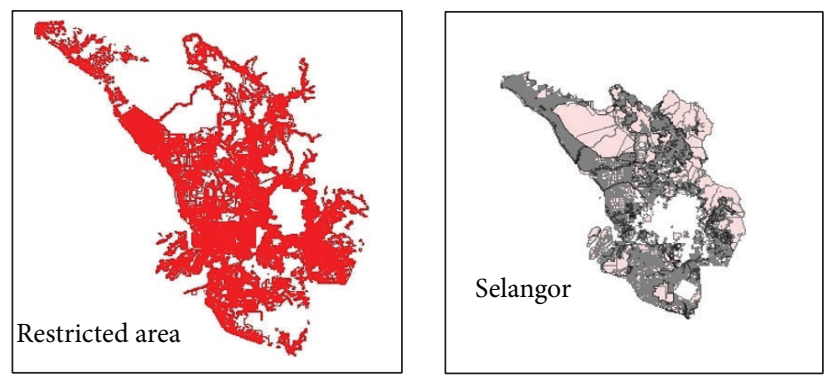

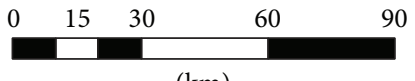

$(\mathrm{km})$

(b)

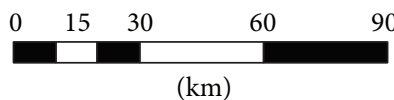

(c)

FIgURE 4: Selangor and potential landfill sites maps.

This table compares land use and operational methods to create a positive social impression with respect to the landfill site. For instance, the second expert in the first group indicates that operation method is slightly more important than the land use. In Table 3, the relative weights are ranked in increasing order. Because four preferences are contained in each set, the median weight set is determined using (2). Therefore, the second and the third quarters represent the MRSS and determine the relative importance set of the landfill siting criteria. The obtained relative importance set displayed in Table 3 is " $1 ; 5 ; 7 ; 3$." This technique guarantees representation of the best set regardless of the origin of the responses. This result is displayed in Table 3 in which an increasing response rank is required regardless of the sector.

3.3. Final Priority Selection. The ANP uses three matrices: unweighted supermatrix, weighted supermatrix, and limit matrix. The unweighted supermatrix is the relative importance of all main components and subcomponents.
TABLE 3: Ranked comparison of the importance of land use with operational methods.

\begin{tabular}{lcccc}
\hline \multicolumn{5}{c}{ Ranked experts preferences } \\
\hline Expert group number 1 & 0.20 & 0.33 & 1 & 7 \\
Expert group number 2 & 0.14 & $\mathbf{1}$ & 1 & 3 \\
Expert group number 3 & 3 & $\mathbf{5}$ & 7 & 7 \\
Expert group number 4 & 0.20 & 3 & $\mathbf{3}$ & 3 \\
\hline
\end{tabular}

TABle 4: Priorities group matrix of the main criteria.

\begin{tabular}{lcccc}
\hline Sector & Land use & Environmental & Operational & Social \\
\hline Land use & 0.183 & 0.143 & 0.116 & 0.540 \\
Environmental & 0.526 & 0.571 & 0.488 & 0.0 \\
Operational & 0.204 & 0.286 & 0.275 & 0.163 \\
Social & 0.087 & 0.0 & 0.121 & 0.297 \\
\hline
\end{tabular}

TABLE 5: Final priorities of the main criteria.

\begin{tabular}{lc}
\hline Main criteria & Final priority \\
\hline Land use & 0.142 \\
Environmental & 0.546 \\
Operational & 0.262 \\
Social & 0.05 \\
\hline
\end{tabular}

The weighted supermatrix clarifies the values of each group and its elements. The limit matrix represents the priorities results and is obtained by raising the weighted supermatrix to a high power to acquire constant values.

Table 4 shows the priorities group matrix. Zero values mean that there are no interconnections between the criteria in the matrix; this independence is shown in Figure 2 in which no interactions are displayed between the environmental and social groups. The priority value of each main criterion in Table 4 depends on the relationship between the criteria groups. For instance, operations have an importance of 0.286 with respect to minimizing the landfill effects on the environment. This importance decreases to 0.16 when considering the creation of a positive social opinion with respect to the landfill site.

The final priorities of the main criteria group are shown in Table 5, and the highest rank of 0.54 is shown for environmental criteria, followed by operational methods and techniques (priority rank of 0.26 ). A landfill should be located and designed to protect human health and to conserve the environment. Therefore, environmental criteria gained the highest rank and this is the present worldwide trend [29]. In addition, according to the obtained results we can conclude that the social and operational criteria are considered to be insignificant by stakeholders. However, such results were reported by many researchers. For instance, Ismail (2011) [46] reported ground water, surface water, and protected area as the most important factors followed by land slope. Afzali et al. (2011) ranked the surface water (19\%) followed by ground water (13\%) as the most important physical criteria. Nadi et al. (2010) [47] ranked the hydrology and water as the most important criteria (33.4\%) and social and financial 
TABLE 6: Weight priorities of the overall subcriteria.

\begin{tabular}{lccc}
\hline Group & Criteria & $\begin{array}{c}\text { Priority normalized } \\
\text { by group }\end{array}$ & Final priority \\
\hline \multirow{2}{*}{ Environmental } & SW & 0.317 & 0.173 \\
& GW & 0.157 & 0.085 \\
& FZ & 0.181 & 0.099 \\
\hline \multirow{2}{*}{ Land use } & TO & 0.345 & 0.058 \\
& CS & 0.409 & 0.083 \\
Operational & HA & 0.591 & 0.038 \\
& LA & 0.145 & 0.135 \\
Social & SA & 0.511 & 0.091 \\
& AE & 0.344 & 0.029 \\
\hline
\end{tabular}

SW: proximity to surface water, GW: depth of ground water, FZ: proximity to fault zone, TO: topology, CS: proximity to critical site, RA: road accessibility, HD: haul distance, LA: landfill area, SA: soil availability, AE: aesthetic, and NS: nearest settlement.

TABLE 7: Summary of the rankings and SI for the potential landfill sites.

\begin{tabular}{lcccccccccccc}
\hline \multirow{2}{*}{ Site number } & \multicolumn{4}{c}{ Environmental } & \multicolumn{4}{c}{ Land use } & \multicolumn{3}{c}{ Operational } & \multicolumn{2}{c}{ Social } \\
& SW & GW & FZ & TO & CS & RA & HD & LA & SA & AE & NS \\
\hline LF1 & 0.173 & 0.085 & 0.040 & 0.113 & 0.058 & 0.017 & 0.038 & 0.135 & 0.091 & 0.029 & 0.004 & 0.782 \\
LF2 & 0.173 & 0.068 & 0.040 & 0.113 & 0.058 & 0.083 & 0.038 & 0.135 & 0.091 & 0.029 & 0.004 & 0.832 \\
LF3 & 0.035 & 0.017 & 0.020 & 0.188 & 0.058 & 0.083 & 0.038 & 0.135 & 0.091 & 0.029 & 0.008 & 0.702 \\
LF4 & 0.138 & 0.068 & 0.099 & 0.113 & 0.058 & 0.083 & 0.038 & 0.135 & 0.091 & 0.023 & 0.013 & 0.859 \\
LF5 & 0.104 & 0.085 & 0.020 & 0.075 & 0.058 & 0.066 & 0.038 & 0.135 & 0.091 & 0.017 & 0.021 & 0.711 \\
LF6 & 0.138 & 0.051 & 0.040 & 0.150 & 0.058 & 0.064 & 0.038 & 0.135 & 0.091 & 0.017 & 0.004 & 0.787 \\
LF7 & 0.035 & 0.017 & 0.099 & 0.113 & 0.058 & 0.083 & 0.038 & 0.135 & 0.091 & 0.029 & 0.008 & 0.706 \\
\hline
\end{tabular}

criteria as the least important criteria with weight equal to $15.5 \%$ and 15.3, respectively. Demesouka et al. (2013) indicated the hydrology as the most important factor followed by the environmental criteria and ranked the social and economic factors as the least important or insignificant factors. In a study done by [48], the social and technoeconomic criteria gained the lowest importance of $9 \%$ and $6 \%$, respectively. Moreover, such conclusion was also reported by Ismail (2011) for landfill siting in Malaysia because the social and operational (technical) criteria can be extended and modified. A study done by [49] reported that urban area and water resources are the most important criteria that should be considered for construction intermunicipality landfill. However, sometimes it is inappropriate to compare among studies from different countries because the obtained weights are dependent upon surveyed respondents, different studied factors, and different local and environmental conditions.

The final priorities of the factors related to landfill site selection are shown in Table 6 . The overall highest rank is for land topology (18.8\%) because of its direct effect on both surface water and groundwater as well as on soil erosion by control of water runoff [50]. Surface water is the second highest factor (17.3\%). Surface water can easily become polluted and can therefore propagate pollutants. The third highest rank is for landfill area (13.5\%); this ranking is due to the requirement to locate the landfill in a manner that reduces the price of the land because the land price represents the highest cost for a landfill. In addition, the landfill size must be optimized to minimize environmental effects and the costs associated with identifying a new landfill site.

However, applying (2) produced Table 8 that describes the preference sets of the performed sixty-three comparisons. Each element in the set represents the preferences of each expert group. Table 9 is a result of applying the preferences sets in ANP and represents the unweighted supermatrix. It is two-dimensional matrix of element by element, and it provides relative importance of all components (main criteria and subcriteria) [45]. The weighted and limit matrices are described by Tables 10 and 11, respectively. In the limit matrix, the constant values of each value are determined by taking the necessary limit of the weighted supermatrix [38]. Social criteria and haul distance got the lowest rank. The influence of these criteria on the design of a landfill can be minimized with suitable arrangements. For example, if appropriate transfer station is used, then the solid waste hauling cost is reduced. Additionally, planted buffer zones and special landscaping can reduce visual and odor pollution to minimize the nuisance to neighbors. Moreover, shifting traffic as far as possible 
TABLE 8: MRSS preference sets.

\begin{tabular}{|c|c|c|c|}
\hline Number & Comparison target & Comparison elements & MRSS preference sets \\
\hline 1 & \multirow{3}{*}{ To create positive social opinion } & Land use (operational) & $0.33,1,7$, and 3 \\
\hline 2 & & Land use (social) & $1,1,5$, and 1 \\
\hline 3 & & Operation (social) & $0.2,1,0.2$, and 1 \\
\hline 4 & \multirow{3}{*}{$\begin{array}{l}\text { To protect environmental } \\
\text { elements }\end{array}$} & Environmental (land use) & $1,3,5$, and 5 \\
\hline 5 & & Environmental (operational) & $1,1,5$, and 1 \\
\hline 6 & & Land use (operational) & $1,1,5$, and 1 \\
\hline 7 & \multirow{6}{*}{$\begin{array}{l}\text { For sustainable and strategic land } \\
\text { use planning }\end{array}$} & Environmental (land use) & $1,3,3$, and 3 \\
\hline 8 & & Environmental (operational) & $1,1,7$, and 3 \\
\hline 9 & & Environmental (social) & $5,1,7$, and 7 \\
\hline 10 & & Land use (operational) & $0.33,0.2,1$, and 3 \\
\hline 11 & & Land use (social) & $1,0.14,3$, and 3 \\
\hline 12 & & Operation (social) & $1,1,5$, and 5 \\
\hline 13 & \multirow{6}{*}{$\begin{array}{l}\text { To minimize the operational cost } \\
\text { and to operate the landfill with } \\
\text { best available techniques and } \\
\text { best environmental practices }\end{array}$} & Environmental (land use) & $1,7,5$, and 5 \\
\hline 14 & & Environmental (operational) & $1,1,3$, and 3 \\
\hline 15 & & Environmental (social) & $1,1,5$, and 3 \\
\hline 16 & & Land use (operational) & $0.33,1,1$, and 1 \\
\hline 17 & & Land use (social) & $1,0.2,3$, and 1 \\
\hline 18 & & Operation (social) & $5,1,5$, and 3 \\
\hline 19 & \multirow{5}{*}{ To protect surface water } & Proximity to critical sites (road accessibility) & $0.2,0.11,0.33$, and 1 \\
\hline 20 & & Soil cove availability (landfill area) & $0.33,1,5$, and 1 \\
\hline 21 & & Avoiding faulting zones (depth of ground water) & $0.33,0.14,3$, and 1 \\
\hline 22 & & Avoiding faulting zones (topology) & $1,0.14,3$, and 1 \\
\hline 23 & & Depth of ground water (topology) & $3,1,1$, and 1 \\
\hline 24 & \multirow{4}{*}{$\begin{array}{l}\text { To reduce the effects on fault } \\
\text { zones }\end{array}$} & Landfill area (soil cover) & $1,0.2,5$, and 3 \\
\hline 25 & & Proximity to surface water (depth of ground water) & $1,1,3$, and 1 \\
\hline 26 & & Proximity to surface water (topology) & $1,1,1$, and 1 \\
\hline 27 & & Depth of ground water (topology) & $1,1,1$, and 1 \\
\hline 28 & \multirow{4}{*}{$\begin{array}{l}\text { To protect the ground water from } \\
\text { pollutants }\end{array}$} & Landfill area (soil cover) & $1,1,5$, and 1 \\
\hline 29 & & Proximity to surface water (avoiding fault zones) & $1,1,1$, and 1 \\
\hline 30 & & Proximity to surface water (topology) & $1,1,0.2$, and 0.3 \\
\hline 31 & & Avoiding fault zones (topology) & $1,1,5$, and 3 \\
\hline 32 & \multirow{4}{*}{$\begin{array}{l}\text { To reduce altering the land } \\
\text { topology }\end{array}$} & Landfill area (soil cover) & $1,0.14,3$, and 1 \\
\hline 33 & & Proximity to surface water (avoiding fault zones) & $1,1,3$, and 3 \\
\hline 34 & & Proximity to surface water (topology) & $1,1,1$, and 1 \\
\hline 35 & & Avoiding fault zones (topology) & $1,0.2,0.33$, and 1 \\
\hline 36 & \multirow{5}{*}{ To protect the critical sites } & Proximity to surface water (avoiding fault zones) & $1,1,5$, and 1 \\
\hline 37 & & Proximity to surface water (depth of ground water) & $1,1,5$, and 7 \\
\hline 38 & & Avoiding fault zones (depth of ground water) & $1,1,3$, and 3 \\
\hline 39 & & Aesthetic (proximity to living settlement) & $0.33,1,5$, and 3 \\
\hline 40 & & Road accessibility (proximity to critical sites) & $0.33,1,1$, and 3 \\
\hline 41 & \multirow{3}{*}{$\begin{array}{l}\text { To locate landfill in places easily } \\
\text { accessed by roads }\end{array}$} & Proximity to surface water (topology) & $0.33,1,0.2$, and 0.2 \\
\hline 42 & & Haul Distance (landfill Area) & $5,5,5$, and 5 \\
\hline 43 & & Aesthetic (proximity to living settlement) & $0.33,1,3$, and 1 \\
\hline 44 & \multirow{4}{*}{$\begin{array}{l}\text { To minimize the solid waste haul } \\
\text { distance }\end{array}$} & Proximity to surface water (topology) & $1,3,5$, and 1 \\
\hline 45 & & Proximity to critical sites (road accessibility) & $0.33,0.2,0.2$, and 0.14 \\
\hline 46 & & Landfill area (soil cover) & $1,1,1$, and 1 \\
\hline 47 & & Aesthetic (proximity to living settlement) & $0.33,0.3,1$, and 1 \\
\hline
\end{tabular}


TABLe 8: Continued.

\begin{tabular}{|c|c|c|c|}
\hline Number & Comparison target & Comparison elements & MRSS preference sets \\
\hline 48 & \multirow{11}{*}{$\begin{array}{l}\text { To determine the optimum } \\
\text { landfill area }\end{array}$} & Proximity to surface water (avoiding fault zones) & $1,1,3$, and 3 \\
\hline 49 & & Proximity to surface water(depth of ground water) & $1,1,3$, and 5 \\
\hline 50 & & Proximity to surface water(topology) & $3,1,7$, and 7 \\
\hline 51 & & Avoiding fault zones (depth of ground water) & $1,1,3$, and 3 \\
\hline 52 & & Avoiding fault zones (topology) & $3,1,7$, and 3 \\
\hline 53 & & Depth of ground water (topology) & $0.33,1,3$, and 3 \\
\hline 54 & & Proximity to critical sites (road accessibility) & $1,1,3$, and 5 \\
\hline 55 & & Solid waste haul distance (landfill area) & $1,1,1$, and 5 \\
\hline 56 & & Solid waste haul distance (soil cover) & $1,1,3$, and 3 \\
\hline 57 & & Landfill area (soil cover) & $0.33,1,5$, and 1 \\
\hline 58 & & Aesthetic (proximity to living settlement) & $0.33,1,1$, and 1 \\
\hline 59 & $\begin{array}{l}\text { To protect the soil cover from } \\
\text { pollution }\end{array}$ & Proximity to surface water (topology) & $0.33,1,0.2$, and 0.33 \\
\hline 60 & \multirow{3}{*}{$\begin{array}{l}\text { To minimize the possibility of } \\
\text { the landfill being seen }\end{array}$} & Proximity to critical sites (road accessibility) & $0.33,0.33,1$, and 1 \\
\hline 61 & & Solid waste haul distance (landfill area) & $1,1,3$, and 1 \\
\hline 62 & & Aesthetic (proximity to living settlement) & $1,0.33,3$, and 1 \\
\hline 63 & $\begin{array}{l}\text { To locate the landfill as far as } \\
\text { possible from settlements }\end{array}$ & Solid waste haul distance (landfill area) & $1,1,7$, and 7 \\
\hline
\end{tabular}

TABLE 9: Unweighted supermatrix.

\begin{tabular}{|c|c|c|c|c|c|c|c|c|c|c|c|}
\hline \multirow{2}{*}{ Group labels } & \multicolumn{4}{|c|}{ Environmental } & \multicolumn{2}{|c|}{ Land use } & \multicolumn{3}{|c|}{ Operational } & \multicolumn{2}{|c|}{ Social } \\
\hline & SW & GW & FZ & TO & $\mathrm{CS}$ & RA & $\mathrm{HD}$ & LA & SA & $\mathrm{AE}$ & NS \\
\hline \multicolumn{12}{|c|}{ Environmental } \\
\hline SW & 0.00 & 0.25 & 0.41 & 0.40 & 0.54 & 0.25 & 0.75 & 0.48 & 0.25 & 0.00 & 0.00 \\
\hline GW & 0.55 & 0.00 & 0.26 & 0.00 & 0.16 & 0.00 & 0.00 & 0.15 & 0.00 & 0.00 & 0.00 \\
\hline $\mathrm{FZ}$ & 0.21 & 0.46 & 0.00 & 0.20 & 0.30 & 0.00 & 0.00 & 0.29 & 0.00 & 0.00 & 0.00 \\
\hline $\mathrm{TO}$ & 0.24 & 0.28 & 0.33 & 0.40 & 0.00 & 0.75 & 0.25 & 0.08 & 0.75 & 0.00 & 0.00 \\
\hline \multicolumn{12}{|l|}{ Land use } \\
\hline CS & 0.25 & 0.00 & 1.00 & 0.00 & 0.33 & 1.00 & 0.17 & 0.75 & 0.00 & 0.33 & 0.00 \\
\hline RA & 0.75 & 0.00 & 0.00 & 1.00 & 0.67 & 0.00 & 0.83 & 0.25 & 0.00 & 0.67 & 1.00 \\
\hline \multicolumn{12}{|l|}{ Operational } \\
\hline HD & 0.00 & 0.00 & 0.00 & 0.00 & 0.00 & 0.83 & 0.00 & 0.49 & 0.00 & 0.67 & 0.83 \\
\hline LA & 0.33 & 0.67 & 0.67 & 0.50 & 0.00 & 0.17 & 0.50 & 0.31 & 1.00 & 0.33 & 0.17 \\
\hline SA & 0.67 & 0.33 & 0.33 & 0.50 & 0.00 & 0.00 & 0.50 & 0.20 & 0.00 & 0.00 & 0.00 \\
\hline \multicolumn{12}{|l|}{ Social } \\
\hline $\mathrm{AE}$ & 0.00 & 0.00 & 0.00 & 0.00 & 0.75 & 0.50 & 0.33 & 0.50 & 0.00 & 0.50 & 1.00 \\
\hline NS & 0.00 & 0.00 & 0.00 & 0.00 & 0.25 & 0.50 & 0.67 & 0.50 & 0.00 & 0.55 & 0.00 \\
\hline
\end{tabular}

from populated areas may minimize noise complaints. In general, these considerations are inexpensive and require minimal labor compared with the other criteria.

Finally, incorporating the participation of conflicting stakeholders minimizes the uncertainty and risk of reproducing homogenous decisions and enhances the quality of the decisions. Additionally, consistent and reliable results must be achieved $[51,52]$. The landfill sitting factors and stakeholders are both predefined and grouped in sets. Stakeholder grouping and interviews are time-saving tools that effectively gather perceptions and values from the experts [53]. However, to ensure an efficient and unbiased representation of the expert judgments, an MRSS was used to rank and calculate the judgment sets $[27,54]$.

3.4. Case Study. As consequence of rapid urbanization and economic growth the solid waste generation is increased dramatically in Selangor state. Owing to this increase, the search for and the provision of an efficient solid waste management method has become an essential matter [55]. Landfill is the main solid waste disposal method in Malaysia [4]. Figure 4(c) shows the map of Selangor including Putrajaya and Kuala Lumpur cities. The restricted area that cannot be used to construct a landfill is shown in Figure 4(b). 
TABLE 10: Weighted supermatrix.

\begin{tabular}{|c|c|c|c|c|c|c|c|c|c|c|c|}
\hline \multirow{2}{*}{ Group labels } & \multicolumn{4}{|c|}{ Environmental } & \multicolumn{2}{|c|}{ Land use } & \multicolumn{3}{|c|}{ Operational } & \multicolumn{2}{|c|}{ Social } \\
\hline & SW & GW & $\mathrm{FZ}$ & TO & $\mathrm{CS}$ & $\mathrm{RA}$ & HD & LA & SA & $\mathrm{AE}$ & NS \\
\hline \multicolumn{12}{|c|}{ Environmental } \\
\hline SW & 0.00 & 0.17 & 0.24 & 0.23 & 0.36 & 0.13 & 0.37 & 0.23 & 0.16 & 0.00 & 0.00 \\
\hline GW & 0.31 & 0.00 & 0.15 & 0.00 & 0.11 & 0.00 & 0.00 & 0.08 & 0.00 & 0.00 & 0.00 \\
\hline $\mathrm{FZ}$ & 0.12 & 0.31 & 0.00 & 0.11 & 0.20 & 0.00 & 0.00 & 0.14 & 0.00 & 0.00 & 0.00 \\
\hline $\mathrm{TO}$ & 0.14 & 0.19 & 0.19 & 0.23 & 0.00 & 0.39 & 0.12 & 0.04 & 0.48 & 0.00 & 0.00 \\
\hline \multicolumn{12}{|l|}{ Land use } \\
\hline CS & 0.04 & 0.00 & 0.14 & 0.00 & 0.08 & 0.18 & 0.02 & 0.09 & 0.00 & 0.18 & 0.00 \\
\hline RA & 0.11 & 0.00 & 0.00 & 0.14 & 0.15 & 0.00 & 0.10 & 0.03 & 0.00 & 0.36 & 0.54 \\
\hline \multicolumn{12}{|l|}{ Operational } \\
\hline HD & 0.00 & 0.00 & 0.00 & 0.00 & 0.00 & 0.17 & 0.00 & 0.14 & 0.00 & 0.11 & 0.14 \\
\hline LA & 0.09 & 0.22 & 0.19 & 0.14 & 0.00 & 0.03 & 0.14 & 0.09 & 0.36 & 0.05 & 0.03 \\
\hline SA & 0.19 & 0.11 & 0.10 & 0.14 & 0.00 & 0.00 & 0.14 & 0.05 & 0.00 & 0.00 & 0.00 \\
\hline \multicolumn{12}{|l|}{ Social } \\
\hline $\mathrm{AE}$ & 0.00 & 0.00 & 0.00 & 0.00 & 0.08 & 0.04 & 0.04 & 0.06 & 0.00 & 0.15 & 0.30 \\
\hline NS & 0.00 & 0.00 & 0.00 & 0.00 & 0.03 & 0.04 & 0.08 & 0.06 & 0.00 & 0.15 & 0.00 \\
\hline
\end{tabular}

TABLE 11: Limit matrix.

\begin{tabular}{|c|c|c|c|c|c|c|c|c|c|c|c|}
\hline \multirow{2}{*}{ Group labels } & \multicolumn{4}{|c|}{ Environmental } & \multicolumn{2}{|c|}{ Land use } & \multicolumn{3}{|c|}{ Operational } & \multicolumn{2}{|c|}{ Social } \\
\hline & SW & GW & $\mathrm{FZ}$ & TO & CS & RA & $\mathrm{HD}$ & LA & SA & $\mathrm{AE}$ & NS \\
\hline \multicolumn{12}{|c|}{ Environmental } \\
\hline SW & 0.173 & 0.173 & 0.173 & 0.173 & 0.173 & 0.173 & 0.173 & 0.173 & 0.173 & 0.173 & 0.173 \\
\hline GW & 0.085 & 0.085 & 0.085 & 0.085 & 0.085 & 0.085 & 0.085 & 0.085 & 0.085 & 0.085 & 0.085 \\
\hline $\mathrm{FZ}$ & 0.099 & 0.099 & 0.099 & 0.099 & 0.099 & 0.099 & 0.099 & 0.099 & 0.099 & 0.099 & 0.099 \\
\hline TO & 0.188 & 0.188 & 0.188 & 0.188 & 0.188 & 0.188 & 0.188 & 0.188 & 0.188 & 0.188 & 0.188 \\
\hline \multicolumn{12}{|l|}{ Land use } \\
\hline CS & 0.058 & 0.058 & 0.058 & 0.058 & 0.058 & 0.058 & 0.058 & 0.058 & 0.058 & 0.058 & 0.058 \\
\hline RA & 0.083 & 0.083 & 0.083 & 0.083 & 0.083 & 0.083 & 0.083 & 0.083 & 0.083 & 0.083 & 0.083 \\
\hline \multicolumn{12}{|l|}{ Operational } \\
\hline $\mathrm{HD}$ & 0.038 & 0.038 & 0.038 & 0.038 & 0.038 & 0.038 & 0.038 & 0.038 & 0.038 & 0.038 & 0.038 \\
\hline LA & 0.135 & 0.135 & 0.135 & 0.135 & 0.135 & 0.135 & 0.135 & 0.135 & 0.135 & 0.135 & 0.135 \\
\hline SA & 0.091 & 0.091 & 0.091 & 0.091 & 0.091 & 0.091 & 0.091 & 0.091 & 0.091 & 0.091 & 0.091 \\
\hline \multicolumn{12}{|l|}{ Social } \\
\hline $\mathrm{AE}$ & 0.029 & 0.029 & 0.029 & 0.029 & 0.029 & 0.029 & 0.029 & 0.029 & 0.029 & 0.029 & 0.029 \\
\hline NS & 0.021 & 0.021 & 0.021 & 0.021 & 0.021 & 0.021 & 0.021 & 0.021 & 0.021 & 0.021 & 0.021 \\
\hline
\end{tabular}

The restriction map was obtained by implementing the guidelines issued by Department of Environment. These guidelines determine the prohibited landfill construction areas that are urban, sensitive ecological areas, heritage and cultural sites, strategic agricultural area like paddy fields, flood plain zones, swamps and water bodies, and parks. Moreover, it suggests a buffer distance, like distance from human settlements $(500 \mathrm{~m})$, highways $(300 \mathrm{~m})$, floodplain areas $(100 \mathrm{~m})$, and proximity to surface water ( $100 \mathrm{~m}$ buffer). The restriction area represents $80 \%$ of the total Selangor area. The top map in Figure 4(a) shows the potential area in green color. After that, seven sites were determined as a potential landfill sites based on their area. The landfill area assumed to be around 100 hectare, and this assumption is based on Pariatamby and Tanaka (2014) recommendation [56] for minimum landfill size required for economically efficient gas collection system and the recommendation for potential impacts of landfill based on its size [57]. The ranks of the potential landfill sites are shown in Table 7 . These ranks were obtained using the results of MRSS-ANP model for site evaluation criteria and Suitability Index (SI), which is the sum of products of the standardized score of each criterion multiplied by the weight of each criterion. The highest ranks are for sites numbers LF4 and LF2, with SI equal to 0.859 and 0.832 , respectively, as shown in Figure 4.

\section{Conclusions}

The siting of undesirable facilities is a process characterized by uncertainty and complexity, as well as multiple and 
conflicting criteria. Determining the site evaluation criteria and constructing the dependence and connections among these factors is the key preliminary step in the siting process. Therefore, an appropriate hierarchical structure must be constructed for the evaluation criteria, and the expert groups must be determined. However, participation of all potential stakeholders in decision-making process is essential to justify and increase the decision acceptance and quality. Moreover, it minimizes the risk and avoids production of identical decision. Stakeholders grouping and interviewing are efficient way to collect their perceptions. Moreover, MRSS is a statistical tool that guarantees gathering unbiased representation of the study society, and thus it was used in this study.

Environmental criteria were assigned the highest priority (54.6\%). Environmental effects have the highest complexity and represent the core of the mitigation measures. The second highest criterion was operational methods and techniques. These processes are pivotal in reducing the effects of a landfill. Social criteria were the least important because the social issues related to landfill sites can be minimized by proper management. Overall, land topology and distance from surface water were the most important subcriteria and have weights equal to $18.8 \%$ and $17.3 \%$, respectively, whereas aesthetics and proximity to the nearest settlement have the lowest priorities of $2.9 \%$ and $2.2 \%$, respectively. These results can be justified as the proposed site is a sanitary landfill with gas and leachate collection system; therefore, the main pollution threats are from the outside, namely, from rainwater. The risk of odor pollution is low because of the applied mitigation measures, that is, leachate and gas collection and buffering zones around the site. Furthermore, the landfill area lacks vegetation; therefore, the topology of the land primarily controls the water runoff and permeability, thus directly affecting soil erosion and surface and ground water.

Finally, this paper incorporated an MRSS and ANP to obtain a methodological framework with which to evaluate the landfill siting criteria. Compared with a traditional ANP, several additional benefits can be achieved using an MRSSANP model. First, this process can enhance handling of the vagueness and imprecision associated with the pairwise comparison process. Second benefit is addressing the interactions, interdependencies, and feedback among the decision evaluation criteria. Third, the combined approach can assist the decision makers to more confidently justify their decisions with minimum funds and expertise. This approach serves as a guide for applying the complex MCDM process to real-life and environmental problems in which the adequate participation of stakeholders and influence factors must be considered. This study represents a first attempt to combine statistical analysis with an ANP to prioritize landfill siting criteria, and further sensitivity analyses are suggested for future work.

\section{Appendix}

For details see Tables 8, 9, 10, and 11 .

\section{Conflict of Interests}

The authors declare that there is no conflict of interests regarding the publication of this paper.

\section{Acknowledgments}

The authors thank Universiti Kebangsaan Malaysia (UKM) and the Malaysian Ministry of Higher Education (MOHE) for funding through FRGS/1/2013/TK03/UKM/02/5.

\section{References}

[1] M. R. Khadivi and S. M. T. Fatemi Ghomi, "Solid waste facilities location using of analytical network process and data envelopment analysis approaches," Waste Management, vol. 32, no. 6, pp. 1258-1265, 2012.

[2] A. Afzali, J. M. V. Samani, and M. Rashid, "Municipal landfill site selection for isfahan city by use of fuzzy logic and analytic hierarchy process," Iranian Journal of Environmental Health Science \& Engineering, vol. 8, no. 3, pp. 273-284, 2011.

[3] M. Colebrook and J. Sicilia, "Undesirable facility location problems on multicriteria networks," Computers \& Operations Research, vol. 34, no. 5, pp. 1491-1514, 2007.

[4] S. T. Tan, H. Hashim, J. S. Lim, W. S. Ho, C. T. Lee, and J. Yan, "Energy and emissions benefits of renewable energy derived from municipal solid waste: analysis of a low carbon scenario in Malaysia," Applied Energy, vol. 136, pp. 797-804, 2014.

[5] K. Hadjibiros, D. Dermatas, and C. Laspidou, "Municipal solid waste management and landfill site selection in Greece: irrationality versus efficiency," Global NEST Journal, vol. 13, pp. 150-161, 2011.

[6] A. Al-Hanbali, B. Alsaaideh, and A. Kondoh, "Using GISbased weighted linear combination analysis and remote sensing techniques to select optimum solid waste disposal sites within Mafraq City, Jordan," Journal of Geographic Information System, vol. 3, no. 4, pp. 267-278, 2011.

[7] D. Geneletti, "Combining stakeholder analysis and spatial multicriteria evaluation to select and rank inert landfill sites," Waste Management, vol. 30, no. 2, pp. 328-337, 2010.

[8] Y. Anifowose, K. Omole, and O. Akingbade, "Waste disposal site selection using remote sensing and GIS: a study of akure and its environs, Southwest-Nigeria," in Proceedings of the COLERM, vol. 2, pp. 526-533, 2012.

[9] M. I. Yesilnacar, M. L. Süzen, B. Ş. Kaya, and V. Doyuran, "Municipal solid waste landfill site selection for the city of Sanliurfa-Turkey: An example using MCDA integrated with GIS," International Journal of Digital Earth, vol. 5, no. 2, pp. 147164, 2012.

[10] N. Holman, "Community participation: using social network analysis to improve developmental benefits," Environment and Planning C: Government \& Policy, vol. 26, no. 3, pp. 525-543, 2008.

[11] T. L. Saaty, Theory and Applications of the Analytic Network Process: Decision Making with Benefits, Opportunities, Costs, and Risks, RWS Publications, 2005.

[12] T. L. Saaty, "Rank from comparisons and from ratings in the analytic hierarchy/network processes," European Journal of Operational Research, vol. 168, no. 2, pp. 557-570, 2006.

[13] C.-W. Tsui and U.-P. Wen, "A hybrid multiple criteria group decision-making approach for green supplier selection in the 
TFT-LCD industry," Mathematical Problems in Engineering, vol. 2014, Article ID 709872, 13 pages, 2014.

[14] M. A. B. Promentilla, T. Furuichi, K. Ishii, and N. Tanikawa, "A fuzzy analytic network process for multi-criteria evaluation of contaminated site remedial countermeasures," Journal of Environmental Management, vol. 88, no. 3, pp. 479-495, 2008.

[15] G. Tuzkaya, S. Önüt, U. R. Tuzkaya, and B. Gülsün, "An analytic network process approach for locating undesirable facilities: an example from Istanbul, Turkey," Journal of Environmental Management, vol. 88, no. 4, pp. 970-983, 2008.

[16] S. Khan and M. N. Faisal, "An analytic network process model for municipal solid waste disposal options," Waste Management, vol. 28, no. 9, pp. 1500-1508, 2008.

[17] A. Aydi, M. Zairi, and H. B. Dhia, "Minimization of environmental risk of landfill site using fuzzy logic, analytical hierarchy process, and weighted linear combination methodology in a geographic information system environment," Environmental Earth Sciences, vol. 68, no. 5, pp. 1375-1389, 2013.

[18] P. V. Gorsevski, K. R. Donevska, C. D. Mitrovski, and J. P. Frizado, "Integrating multi-criteria evaluation techniques with geographic information systems for landfill site selection: a case study using ordered weighted average," Waste Management, vol. 32, no. 2, pp. 287-296, 2012.

[19] O. E. Demesouka, A. P. Vavatsikos, and K. P. Anagnostopoulos, "Suitability analysis for siting MSW landfills and its multicriteria spatial decision support system: method, implementation and case study," Waste Management, vol.33, no. 5, pp.1190-1206, 2013.

[20] M. Eskandari, M. Homaee, S. Mahmoodi, and E. Pazira, "Integrating GIS and AHP for municipal solid waste landfill site selection," Journal of Basic and Applied Scientific Research, vol. 3, no. 4, pp. 588-595, 2013.

[21] K. Ibrahim, M. Syam, and A. I. Al-Omari, "Estimating the population mean using stratified median ranked set sampling," Applied Mathematical Sciences, vol. 4, no. 45-48, pp. 2341-2354, 2010.

[22] K. Ibrahim, "On comparison of some variation of ranked set sampling," Sains Malaysiana, vol. 40, no. 4, pp. 397-401, 2011.

[23] C. E. Husby, E. A. Stasny, and D. A. Wolfe, "An application of ranked set sampling for mean and median estimation using USDA crop production data," Journal of Agricultural, Biological, and Environmental Statistics, vol. 10, no. 3, pp. 354-373, 2005.

[24] S. S. Hossain and H. A. Muttlak, "Hypothesis tests on the scale parameter using median ranked set sampling," Statistica, vol. 66, no. 4, pp. 415-433 (2007), 2006.

[25] J. V. Deshpande, J. Frey, and O. Ozturk, "Nonparametric rankedset sampling confidence intervals for quantiles of a finite population," Environmental and Ecological Statistics, vol. 13, no. 1, pp. 25-40, 2006.

[26] R. Murray, M. Ridout, and J. Cross, "The use of ranked set sampling in spray deposit assessment," Aspects of Applied Biology, vol. 57, pp. 141-146, 2000.

[27] D. A. Wolfe, "Ranked set sampling: its relevance and impact on statistical inference," ISRN Probability and Statistics, vol. 2012, Article ID 568385, 32 pages, 2012.

[28] N. A. Mode, L. L. Conquest, and D. A. Marker, "Incorporating prior knowledge in environmental sampling: ranked set sampling and other double sampling procedures," Environmetrics, vol. 13, no. 5-6, pp. 513-521, 2002.

[29] M. N. A. Azman, M. S. S. Ahamad, T. A. Majid, A. S. Yahaya, and M. H. Hanafi, "Statistical evaluation of pre-selection criteria for industrialized building system (IBS)," Journal of Civil Engineering and Management, vol. 19, no. 1, pp. S131-S140, 2013.

[30] M. Mutlutürk and R. Karagüzel, “The Landfill Area Quality (LAQ) classification approach and its application in Isparta, Turkey," Environmental \& Engineering Geoscience, vol. 13, no. 3, pp. 229-240, 2007.

[31] Z. Adeli and A. M. Khorshiddoust, "Application of geomorphology in urban planning: case study in landfill site selection," Procedia-Social and Behavioral Sciences, vol. 19, pp. 662-667, 2011.

[32] M. Zamorano, E. Molero, Á. Hurtado, A. Grindlay, and Á. Ramos, "Evaluation of a municipal landfill site in Southern Spain with GIS-aided methodology," Journal of Hazardous Materials, vol. 160, no. 2-3, pp. 473-481, 2008.

[33] A. A. Isalou, V. Zamani, B. Shahmoradi, and H. Alizadeh, "Landfill site selection using integrated fuzzy logic and analytic network process (F-ANP)," Environmental Earth Sciences, vol. 68, no. 6, pp. 1745-1755, 2013.

[34] Ş. Şener, E. Şener, B. Nas, and R. Karagüzel, "Combining AHP with GIS for landfill site selection: a case study in the Lake Beyşehir catchment area (Konya, Turkey)," Waste Management, vol. 30, no. 11, pp. 2037-2046, 2010.

[35] B. Nas, T. Cay, F. Iscan, and A. Berktay, "Selection of MSW landfill site for Konya, Turkey using GIS and multi-criteria evaluation," Environmental Monitoring and Assessment, vol. 160, no. 1-4, pp. 491-500, 2010.

[36] M. A. Alanbari, N. Al-Ansari, and H. K. Jasim, "GIS and multicriteria decision analysis for landfill site selection in AlHashimyah Qadaa," Natural Science, vol. 6, no. 5, pp. 282-304, 2014.

[37] S. P. S. Kushwah, K. Rawat, and P. Gupta, "Analysis and comparison of efficient techniques of clustering algorithms in data mining," International Journal of Innovative Technology and Exploring Engineering, vol. 1, no. 3, pp. 109-113, 2012.

[38] M. Sevkli, A. Oztekin, O. Uysal, G. Torlak, A. Turkyilmaz, and D. Delen, "Development of a fuzzy ANP based SWOT analysis for the airline industry in Turkey," Expert Systems with Applications, vol. 39, no. 1, pp. 14-24, 2012.

[39] T. L. Saaty and K. Peniwati, Group Decision Making: Drawing Out and Reconciling Differences, RWS Publications, 2013.

[40] R. Liu, J.-X. Yu, H.-C. Sun, and P. Tian, "Introduction to the ANP super decisions software and its application," Systems Engineering-Theory \& Practice, vol. 8, article 024, 2003.

[41] H. Shahabi, S. Keihanfard, B. B. Ahmad, and M. J. T. Amiri, "Evaluating Boolean, AHP and WLC methods for the selection of waste landfill sites using GIS and satellite images," Environmental Earth Sciences, vol. 71, no. 9, pp. 4221-4233, 2014.

[42] Department of Environment, EIA Guidelines for Development of Solid Waste Sanitary Landfill, Department of Environment, Ministry of Natural Resources and Environment, Putrajaya, Malaysia, 2012.

[43] S. P. Gbanie, P. B. Tengbe, J. S. Momoh, J. Medo, and V. T. S. Kabba, "Modelling landfill location using Geographic Information Systems (GIS) and Multi-Criteria Decision Analysis (MCDA): case study Bo, Southern Sierra Leone," Applied Geography, vol. 36, pp. 3-12, 2013.

[44] C. Simsek, A. Elci, O. Gunduz, and N. Taskin, "An improved landfill site screening procedure under NIMBY syndrome constraints," Landscape and Urban Planning, vol. 132, pp. 1-15, 2014. 
[45] T. L. Saaty, "Decision making with the analytic hierarchy process," International Journal of Services Sciences, vol. 1, no. 1, pp. 83-98, 2008.

[46] S. N. Ismail, Assessing environmental impacts and siting consideration for landfill in Developing Countries: a case study of Malaysia [Ph.D. thesis], University of East Anglia, Norwich, UK, 2011.

[47] B. Nadi, A. Mahmud, N. Ahmad, B. Farjad, B. Arvinpil, and A. Amani, "Managing of urban solid waste by geoinformatics technology," International Geoinformatics Research and Development Journal, vol. 1, pp. 70-80, 2010.

[48] T. Z. Vasiljević, Z. Srdjević, R. Bajčetić, and M. V. Miloradov, "GIS and the analytic hierarchy process for regional landfill site selection in transitional countries: a case study from Serbia," Environmental Management, vol. 49, no. 2, pp. 445-458, 2012.

[49] A. Afzali, S. Sabri, M. Rashid, J. M. V. Samani, and A. N. M. Ludin, "Inter-municipal landfill site selection using analytic network process," Water Resources Management, vol. 28, no. 8, pp. 2179-2194, 2014.

[50] M. Sophocleous, "Interactions between groundwater and surface water: the state of the science," Hydrogeology Journal, vol. 10, no. 1, pp. 52-67, 2002.

[51] M. S. Reed, "Stakeholder participation for environmental management: a literature review," Biological Conservation, vol. 141, no. 10, pp. 2417-2431, 2008.

[52] V. Luyet, R. Schlaepfer, M. B. Parlange, and A. Buttler, "A framework to implement Stakeholder participation in environmental projects," Journal of Environmental Management, vol. 111, pp. 213-219, 2012.

[53] D. Maxwell and J. Parker, "Coordination in food security crises: a stakeholder analysis of the challenges facing the global food security cluster," Food Security, vol. 4, no. 1, pp. 25-40, 2012.

[54] Z. Chen, "The efficiency of ranked-set sampling relative to simple random sampling under multi-parameter families," Statistica Sinica, vol. 10, no. 1, pp. 247-264, 2000.

[55] A. Johari, H. Alkali, H. Hashim, S. I. Ahmed, and R. Mat, "Municipal solid waste management and potential revenue from recycling in Malaysia," Modern Applied Science, vol. 8, no. 4, p. 37, 2014.

[56] A. Pariatamby and M. Tanaka, Municipal Solid Waste Management in Asia and the Pacific Islands, Environmental Science, Springer, Singapore, 2014.

[57] J. S. Lim and P. Missios, "Does size really matter? Landfill scale impacts on property values," Applied Economics Letters, vol. 14, no. 10, pp. 719-723, 2007.

[58] M. Gardašević-Filipović and D. Z. Šaletić, "Multicriteria optimization in a fuzzy environment: the fuzzy analytic hierarchy process," Yugoslav Journal of Operations Research, vol. 20, no. 1, 2010. 


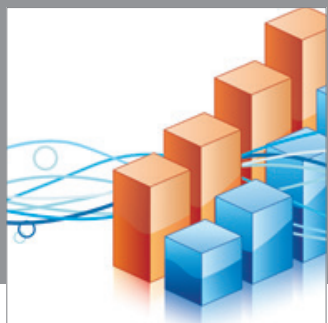

Advances in

Operations Research

mansans

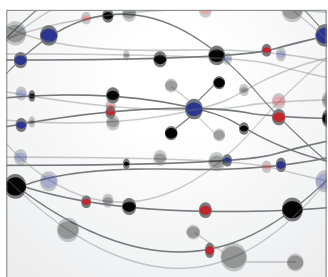

The Scientific World Journal
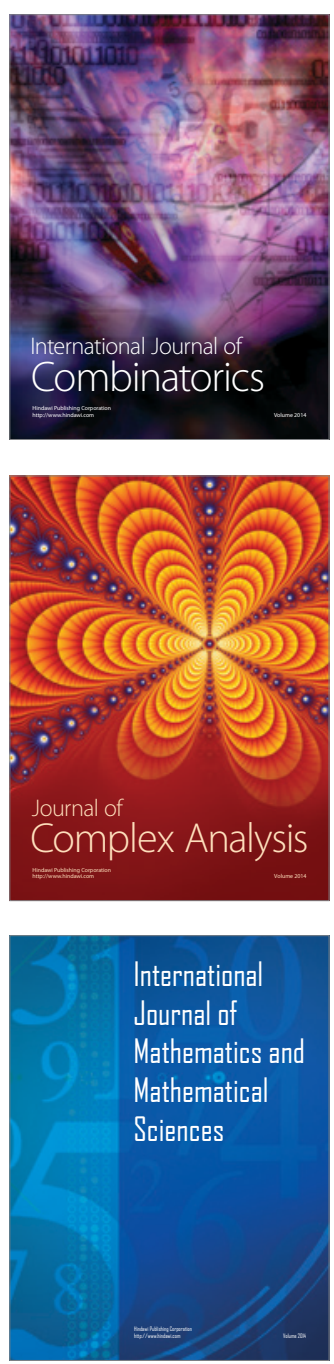
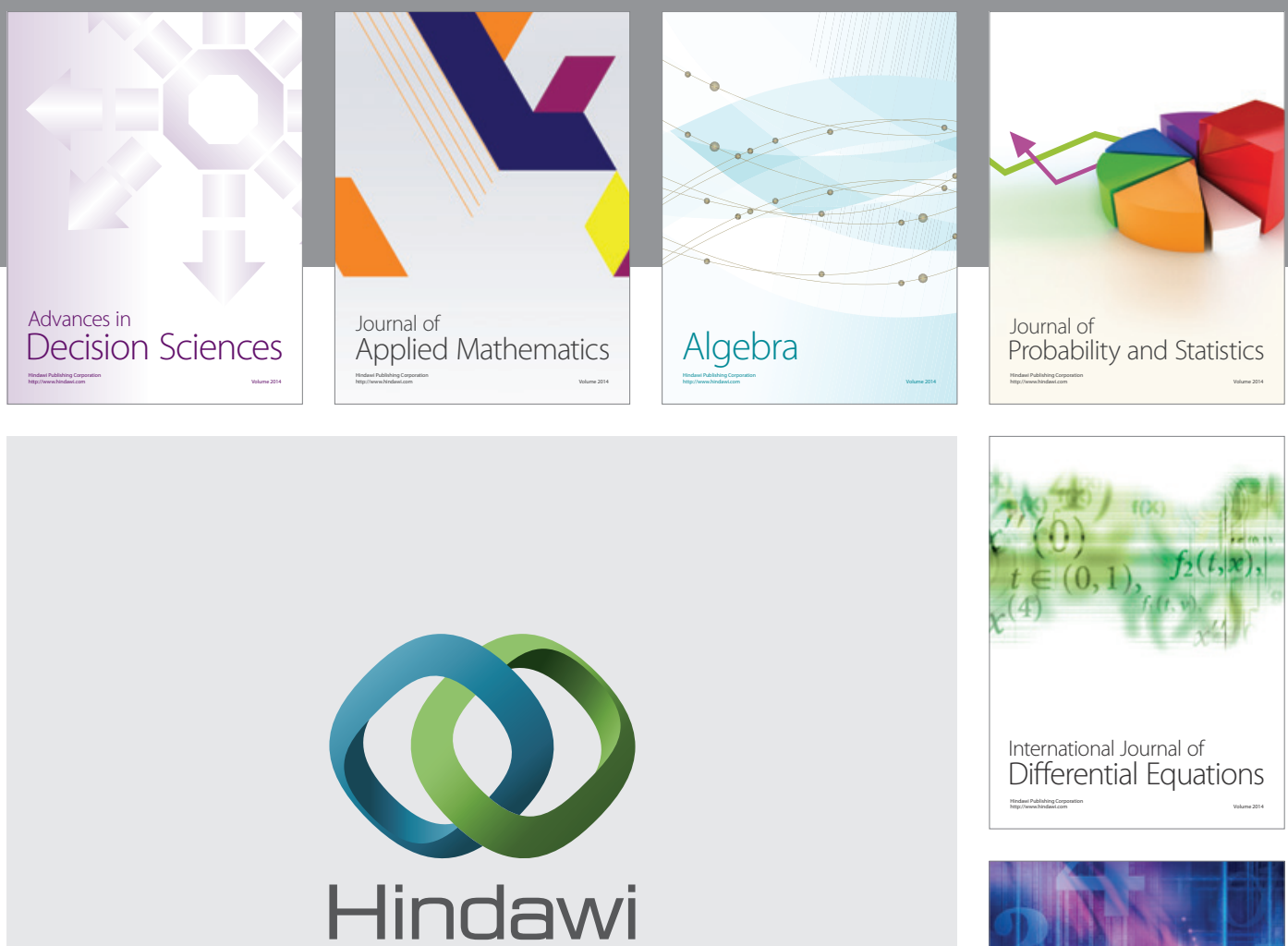

Submit your manuscripts at http://www.hindawi.com
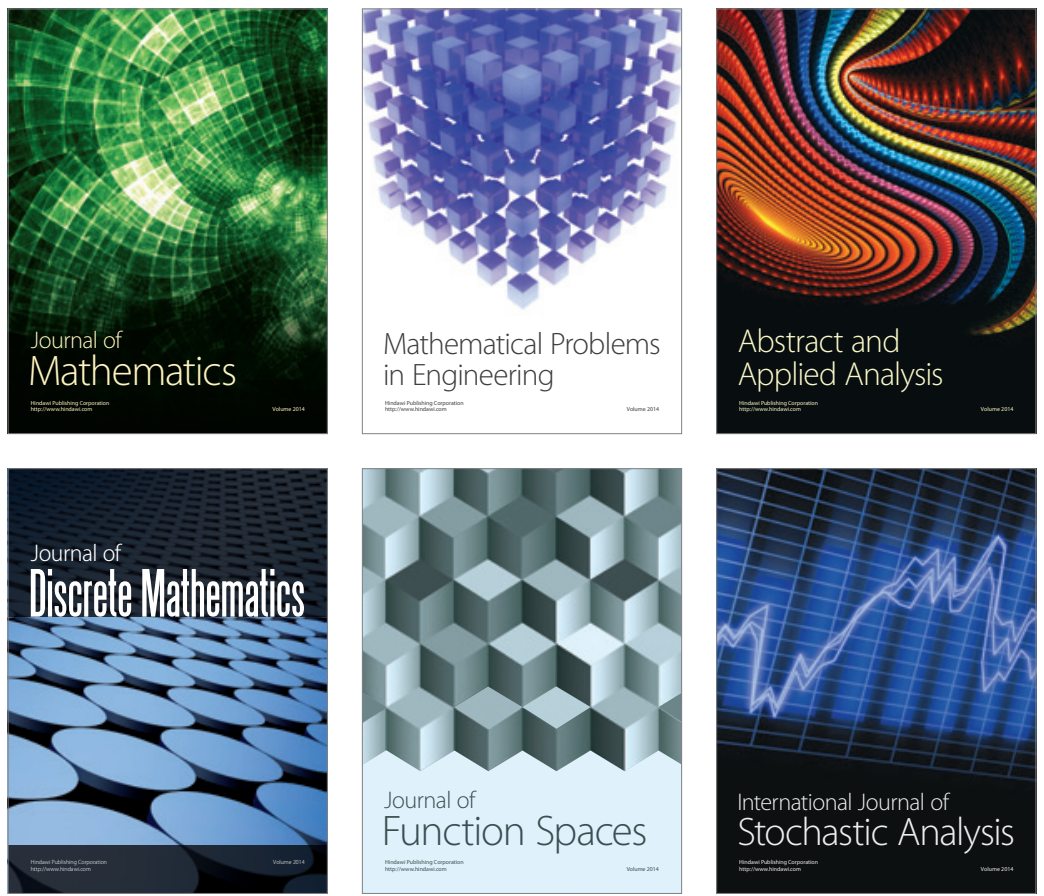

Journal of

Function Spaces

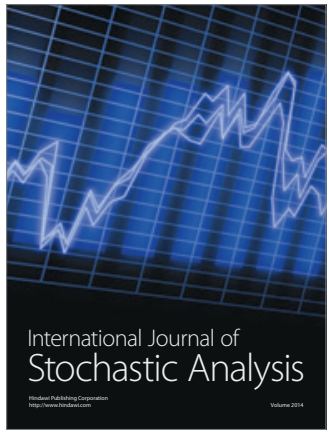

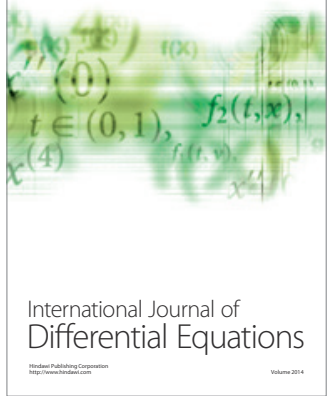
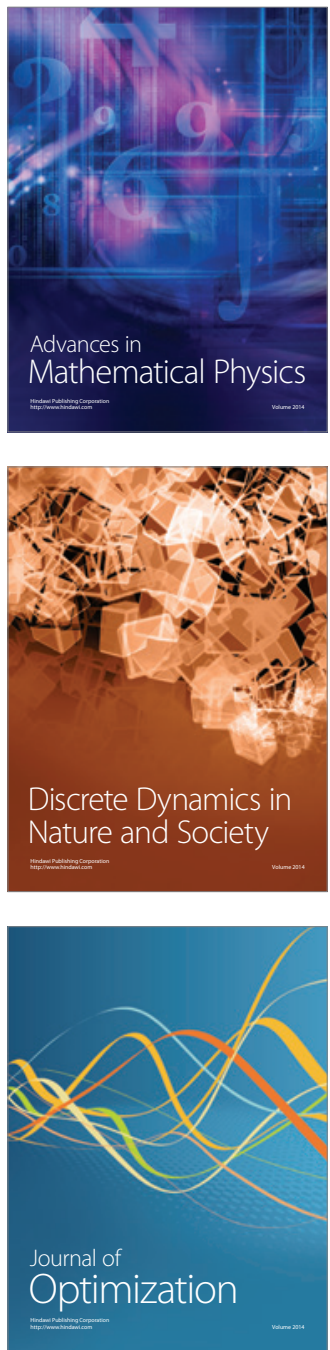